\title{
Potential of Abattoir Waste for Bioenergy as Sustainable Management, Eastern Ethiopia, 2019
}

\author{
Sina Temsgen Tolera $\mathbb{D}^{1}$ and Fekade Ketema Alemu ${ }^{2}$ \\ ${ }^{1}$ Environmental Toxicology, College of Health and Medical Sciences of Haramaya University, P.O. Box 235, Harar, Ethiopia \\ ${ }^{2}$ Public Health in Epidemiology, College of Health and Medical Sciences of Haramaya University, Harar, Ethiopia \\ Correspondence should be addressed to Sina Temsgen Tolera; sinatem3@gmail.com
}

Received 5 December 2019; Revised 21 December 2019; Accepted 3 January 2020; Published 1 February 2020

Academic Editor: Jin-Li Hu

Copyright ( 2020 Sina Temsgen Tolera and Fekade Ketema Alemu. This is an open access article distributed under the Creative Commons Attribution License, which permits unrestricted use, distribution, and reproduction in any medium, provided the original work is properly cited.

\begin{abstract}
Our environment is facing serious problems of high volumes of waste generation and inadequate disposal system in worldwide particularly in developing countries. There is also lack of studies on quantification of abattoir waste and lack of workers awareness towards abattoir waste. Therefore, the purpose of the study was to estimate abattoir waste for bioenergy potential as sustainable management. A cross-sectional study was conducted in four selected abattoirs of Eastern Ethiopia from January $1^{\text {st }}$, 2018 to December $30^{\text {th }}, 2018$. The magnitude of abattoir waste composition was computed based on Aniebo mathematical computational from the actual number of slaughtered livestock. The study demonstrated that four selected abattoirs generate $1,606.403$ ton of abattoir waste per year and using anaerobic digestion of about 85,139 $\mathrm{m}^{3} /$ year of biogas and 111.25 ton/year of biofertilizer can be produced. The biogas or energy from the waste can replace firewood and charcoal and the expensive fossil fuels. Using Banks mathematical computation about $20,054.12 \mathrm{~m}^{3} /$ year production of biogas could replace 20.56 ton/year of energy consumed by liquefied petroleum gas, kerosene, charcoal, furnace oil, petrol, and diesel in average. The current estimated biofertilizer (111.25 ton/year) from four abattoir sites can cover about 2,225 hectares/year with its advantage and efficiency of soil. When turned into cost, about $\$ 55,645$ per year of price could estimate from biogas and biofertilizer. The study concluded that huge amount of biogas and dry biofertilizer yields could produce from abattoir waste through anaerobic digestion. Therefore, installing anaerobic digestion plant is recommended to ensure environmental safety and public health.
\end{abstract}

\section{Introduction}

Abattoirs are where animals such as cattle or goat or sheep and others are slaughtered in for consumption as food and it is also known as slaughterhouse. Livestock production in abattoirs is considered a potential food for the world's needy people, and during meat production, a huge amount of abattoir wastes are generating from them [1]. In this way, abattoir waste management is a major challenge in urban areas throughout the world. Here, threat of abattoir waste resulted from improper managements of abattoir waste can therefore exert oxygen demand on the receiving environment or breed large population of decomposers (microorganism); some of which may be pathogenic [2].

Especially, low-income countries show rapid urban growth that is putting extraordinary pressure on gigantic amount of abattoir waste in the urban [3]. The production of meat, from farm to fork, includes not just meat for human consumption and useful by-products like leather and skin but also waste. Abattoir operations produce a characteristic highly organic waste with relatively high levels of suspended solid, liquid, and fat [4]. These countries are the worst of it given the deficient waste management programs [5]. Most of them have not organized strategy for disposal of solid as well as liquid wastes generated in abattoirs [6]. As FAO [1] reported, these are dumped as solid abattoir wastes without any further processing or composting, or they are washed away.

The nature and quantity of the waste varies at each stage, but includes the carcasses of dead animals, parts of animals which are treated as inedible, bones, hides, and blood. Approximately $50-54 \%$ of each cow, $52 \%$ of each sheep or 
goat, $60-62 \%$ of each pig, $68-72 \%$ of each chicken, and $78 \%$ of each turkey end up as meat consumed by human beings with the remainder becoming waste after processing [7]. Moreover, of abattoir waste, the volume of wastewater from abattoirs is $70-75 \%$ of the abattoir water that contributes to a high organic load as well as a considerable amount of suspended material in the waste [8].

This causes pollution has the potential to pollute air, water, and soil leading to health hazards, FAO [1]. Abattoir wastes affect air quality, agriculture, potable water supplies, and aquatic life, which also pose risks to human and cause methaemoglobinaemia [9].

Yet, a huge amount of wastes generate from the selected Eastern Ethiopia abattoirs and they simply discharge and release their wastes into open environment without any management system or treatment pond. The authors observed that abattoir wastes are not properly treated and managed. Moreover, there was no data available regarding quantification of abattoir waste for sustainable management. Therefore, the purpose of the study was to estimate abattoir waste generated from the selected abattoirs and estimate its potential for bioenergy as sustainable management.

\section{Materials and Methods}

2.1. Study Settings. The study areas are found in Eastern Ethiopia; the first three study areas are Harar Abattoir, Haramaya University Abattoir Enterprise, and Haramaya Abattoirs, which are found in Harar; Haramaya University and Haramaya Towns of about $503 \mathrm{~km}, 508 \mathrm{~km}$, and $527 \mathrm{~km}$, respectively, far from the national capital of Addis Ababa. They are characterized by subtropical highland climate, throughout the year; afternoon temperatures are warm to very warm, cool at mornings, and rain falls between March and October (https://en.wikipedia.org/wiki/Harar).

The second study is Dire Dawa Abattoir, which is found in Dire Dawa Administration and far from Addis Ababa $(453 \mathrm{~km})$. It has $9^{\circ} 36^{\prime} \mathrm{N}, 41^{\circ} 52^{\prime} \mathrm{E}$ latitude and longitude with coordinates of $9^{\circ} 36^{\prime} \mathrm{N}, 41^{\circ} 52^{\prime} \mathrm{E}$. The city is characterized by hot semiarid climate. The region has two rain seasons, that is, a small rain season from March to April and a more pronounced rain season that extends from July to August (https://en.wikipedia.org/wiki/Dire_Dawa).

2.2. Study Design. A cross-sectional study was conducted in the selected abattoirs of Eastern Ethiopia, namely, Haramaya, Haramaya University Enterprise, Harar, and Dire Dawa Abattoirs.

2.3. Abattoir Waste Estimation Methods. A number of slaughtered livestock such as cattle, goats, and sheep were collected from January 1, 2018 to December 30, 2018 from each registry municipalities. For abattoir waste generation, Aniebo et al. [4] mathematical model was applied. One cattle could produce $12.6 \mathrm{~kg}$ of blood waste, $8.0 \mathrm{~kg}$ of intestinal content waste, $6.4 \mathrm{~kg}$ of tissue waste, and $11.8 \mathrm{~kg}$ of bone waste (total 38.8). Similarly, one slaughtered goat/sheep could generate $0.72 \mathrm{~kg}$ (blood waste), $1.25 \mathrm{~kg}$ (intestinal content waste), $0.8 \mathrm{~kg}$ (tissue waste), and $2.06 \mathrm{~kg}$ (bone waste) (total $4.83 \mathrm{~kg}$ ).

$$
\sum(\mathrm{BLw}+\mathrm{Bnw}+\mathrm{Icw}+\mathrm{Tw}) * N
$$

where BLw is the blood waste, Bnw is the bone waste, Icw is the intestinal content waste, and Tw is the tissue waste; $N$ is the number of slaughtered livestock.

2.3.1. Estimation of Biogas Production from Abattoir Waste. In this study, biogas production was calculated following the model of Rao et al. [10], in which it states 1 ton $(1,000 \mathrm{~kg})$ of abattoir waste which produces $53 \mathrm{~m}^{3}$ biogas that is $1 \mathrm{~kg}$ of abattoir waste can produce $0.053 \mathrm{~m}^{3}$ of biogas. Hence, the volume of biogas produced (VBP) may be obtained using the following formula:

$$
\mathrm{VBP}=\mathrm{AWG} * 0.053 \mathrm{~m}^{3} / \mathrm{kg}
$$

(1) Estimation of Energy from Biogas. According to [11], the energy potential of biogas generated is based on the calorific value (high heating value) of the methane content and Rohstoffe [12] stated that the average calorific value of biogas is $21-23.5 \mathrm{MJ} / \mathrm{m}^{3}$ (approximately $22.0 \mathrm{MJ} / \mathrm{m}^{3}$ ). Commonly, energy is expressed as kilowatt hour $(\mathrm{kWh})$ and $3.6 \mathrm{MJ}$ is equal to $1 \mathrm{kWh}$. If the $22.0 \mathrm{MJ} / \mathrm{m}^{3}$ of biogas is converted to $\mathrm{kWh}, 1 \mathrm{~m}^{3}$ of biogas has an energy potential of $6.1 \mathrm{kWh}$. Energy (electricity and heat) potential of biogas was estimated based on the energy conversion methods formulated by Banks [13]. According to Banks [13], the efficiency of biogas to be converted to electricity is $35 \%$, and therefore, the electricity production potential of $1 \mathrm{~m}^{3}$ of biogas is $2.14 \mathrm{kWh}$ (i.e., its energy potential of $6.1 \mathrm{kWh} \times 0.35$ ). Therefore, the electricity production potential (EPP), kWh, may be obtained using the following formula:

$$
\mathrm{EPP}=\mathrm{VBPm} * 2.14 \mathrm{kWh} \text {. }
$$

Similarly, Banks [13] indicated that the efficiency of biogas to be converted to heat energy is $50 \%$, and thus, the heat production potential of $1 \mathrm{~m}^{3}$ of biogas is $3.1 \mathrm{kWh}$ (i.e., energy potential of $6.1 \mathrm{kWh} \times 0.5)$. The heat production potential (HPP), kWh, may be estimated as follows:

$$
\mathrm{HPP}=\mathrm{VBP} * 3.1 \mathrm{kWh} .
$$

(2) Reduction of GHGs Using Biogas Technology. The Greenhouse emission from dumping sites calculated based on [14-16] mathematical computation is summarized as follows:

$$
\begin{aligned}
\text { GHG emission }= & {[((\mathrm{Q} \times \mathrm{DOC} \times \mathrm{DOCF} \times \mathrm{F} 1 \times 1.336)} \\
& -\mathrm{R}) \times(1-\mathrm{OX})] \times 25
\end{aligned}
$$

where $Q$ is the quantity of abattoir waste expressed in tons/kg from waste records; DOC is the degradable organic carbon expressed as a proportion of abattoir waste (default value $(\mathrm{DV})=0.12$ ); DOCF is the fraction of degradable organic carbon dissimilated for the abattoir waste $(\mathrm{DV}=0.7) ; \mathrm{F} 1$ is the methane fraction generated from dumping gas $(\mathrm{DV}=0.50) ; 1.336$ is the conversion rate of 
carbon to methane; $\mathrm{R}$ is the recovered methane during the year, measured in $\mathrm{kg}$ or tons (here no recovered methane); $\mathrm{OX}$ is the oxidation factor (DV $=0.1$ for well-managed and (DV $=0$ for un managed); and 25 is the $\mathrm{CH}_{4}$ global warming potential used to convert the quantity of methane emitted to $\mathrm{CO}_{2}$ eq from the quantity of abattoir waste produced.

$$
\operatorname{GHG} \text { emissions }\left(t \mathrm{CO}_{2} \mathrm{eq}\right)=\mathrm{Qj} \times \mathrm{EFj}
$$

where $t$ is the unit for waste either by ton or $\mathrm{kg} ; \mathrm{CO}_{2} \mathrm{eq}$ is the $\mathrm{CO}_{2}$ in equivalence; $\mathrm{Qj}$ is the quantity of waste by type $\mathrm{j}$ (here is only abattoir waste); $\mathrm{EFj}$ is the emission factor of waste type $\mathrm{j}$ for biogas $\left(0.02 \mathrm{kgCO}_{2} \mathrm{eq}\right)$.

To know the difference, the emission of GHGs from biogas production will be calculated:

$$
\begin{aligned}
\text { Reduction of the GHGs using biogas }= & \sum \text { Equation } 5 \\
& -\sum \text { Equation } 6 .
\end{aligned}
$$

(3) Equivalence of Biogas with Expensive Fossil Fuels. According to Blottnitz (2010) and B-Sustain [14] energy estimation, utilization $1 \mathrm{~m}^{3}$ of biogas is equivalent to coefficient factor of $0.45 \mathrm{~kg}$ liquefied petroleum gas (LPG), $0.6 \mathrm{~kg}$ kerosene $(\mathrm{K})$, $3.50 \mathrm{~kg}$ charcoal/fire wood, $0.4 \mathrm{~kg}$ furnace oil (F), $0.7 \mathrm{~kg}$ petrol $(\mathrm{P})$, and $0.5 \mathrm{~kg}$ diesel (D) in the same activities.

$$
\sum \mathrm{CFF} * N
$$

where CFF is each of above coefficient factor; $N$ is the volume of biogas produced (i.e., from Equation (2)).

(4) Estimation of Cost from Biogas Energy. Amount of energy produced was estimated based on the current Ethiopian Electric Power Corporation/EEPC [17] into cost; i.e., the minimum cost (tariff) of $1 \mathrm{kWh}$ of electricity or heat is 0.021USD (0.57 ETB).

$$
\begin{aligned}
\text { Cost }= & (\text { Equation } 5 \times 0.57 \mathrm{ETB}) \\
& +(\text { Equation } 6 \times 0.57 \mathrm{ETB})
\end{aligned}
$$

2.3.2. Biofertilizer Yield Potential Estimation Methods. According to [11], the coefficients used in estimating biofertilizer yields were based on the fraction of the dry mass (DM) portion of organic waste that is not converted to biogas. Therefore, in this study, biofertilizer was estimated based on the coefficient fraction of the dry mass (DM) and volatile solid (VS) portion of abattoir waste. According to Deublien and Steinhauser [18], the DM percentage of fresh organic wastes was given as $15 \%$ for abattoir waste, while the volatile solid (VS) is the potentially dry mass (DM) of abattoir waste converted into gas (i.e., dry mass minus mineral content), which was calculated by multiplying $85 \%$ with DM of abattoir waste. In this study, the following formulas were used for calculating DM and VS:

$$
\begin{aligned}
\mathrm{DM} & =\mathrm{AWG} * 0.15(15 \%), \\
\mathrm{VS} & =\mathrm{DM} * 0.85(85 \%) .
\end{aligned}
$$

Biofertilizer production was estimated from abattoir waste based on Deublien and Steinhauser [18] coefficient fraction model as the following equations of the dry mass (DM) portion, and therefore, based on this principle, the biofertilizer yield (BFY) of the abattoir waste was calculated considering DM and VS. But according to Burke (2000), $60 \%$ of VS is the actual fraction taken to be converted to biogas and the remaining $40 \%$ portion of VS was considered in BFY computation. Hence, the potential of BFY was deduced as follows:

$$
\mathrm{BFY}=(\mathrm{DM}-\mathrm{VS})+(40 \% * \mathrm{VS})
$$

2.3.3. Estimation of Cost from Biofertilizer Production. Based on the Ethiopian Agriculture Ministry Report (2017/18) report, $50 \mathrm{~kg}$ of UREA and DAP fertilizers are equal to 1,230 Ethiopian birr (ETB) and 11,455 ETB, respectively. We assumed that the price of biofertilizer yield (BFY) was reduced by half $(\approx 50 \%)$ from current price of chemical fertilizers (UREA and DAP). This reduction was assumed that the biofertilizer and its benefits among our farmers may have low acceptance due to limited awareness about it.

$$
\text { Cost of BFY }=50 \mathrm{~kg} \text { of BFY } * \text { US } \$ 23.70(600 \mathrm{ETB}) \text {. }
$$

2.4. Dissemination of the Study. The findings of the study were disseminated to Haramaya University Research Office, Haramaya, Harar, and Dire Dawa Abattoirs. In addition, attempts are to be made to publish the study.

2.5. Data Analysis. Data was entered into SPSS, Version 20, for analysis. Descriptive statistics such as frequency $(\mathrm{F})$, range, mean $(\mathrm{M})$, sum, percentage, and standard deviation (SD) are for numerical data to summarize and describe the data to make them more graspable.

2.6. Ethical Consideration. Permission to conduct this grant research coded "HUKT-2018-01-03-63" was provided by Haramaya University Research Partnership and Group Directorate. The reviewer of proposal and Ethics Committee of Haramaya University approved this research project. Then, Haramaya University Health and Medical Sciences has written a formal letter to Haramaya Town, Haramaya University Enterprise, Harar Town, and Dire Dawa Municipality Authority abattoir service for realization of legal research.

\section{Result}

3.1. Abattoir Waste Composition and Generation. Annually, about $12,339,39,281,10,170$, and 4,380 of livestock such as cattle, goats, and sheep were slaughtered in Harar Abattoir, Dire Dawa Abattoir, Haramaya, and Haramaya University Enterprise (HU-E) Abattoirs, respectively (Table 1). From a total of 66,170 of slaughtered livestock, more than 3,315.36 ton/year of meat could distribute for surrounding 
TABLE 1: Annual slaughtered livestock and estimated abattoir waste from the selected abattoirs, 2019.

\begin{tabular}{|c|c|c|c|c|c|c|}
\hline \multirow{2}{*}{ Name of abattoirs } & \multirow{2}{*}{ Livestock (no) } & \multicolumn{5}{|c|}{ Principal type of abattoir waste compositions } \\
\hline & & Blood waste (ton) & Bone waste (ton) & Intestinal content (ton) & Tissue waste (ton) & Total waste (ton) \\
\hline Harar & 12,339 & 72.33 & 68.61 & 46.42 & 37.01 & 224.37 \\
\hline Dire Dawa & 39,281 & 316.17 & 318.36 & 213.49 & 167.57 & $1,015.59$ \\
\hline Haramaya & 10,170 & 49.41 & 78.24 & 36.62 & 27.97 & 192.25 \\
\hline HU-E & 4,380 & 56.57 & 52.97 & 35.92 & 28.73 & 174.19 \\
\hline Grand total & 66,170 & 494.47 & 518.19 & 33.24 & 261.29 & $1,606.40$ \\
\hline
\end{tabular}

community from January to December 2018 (Table 1). During production of meat about 224.37 ton/year, 1,015.59 ton/year, 192.25 ton/year, and 174.19 ton/year of abattoir wastes was estimated from Harar Abattoir, Dire Dawa City, Haramaya Town, and Haramaya University Enterprise Abattoirs, respectively (Table 1 ).

From total abattoir waste generated, the percentage of abattoir waste composition weight is generated from each abattoirs is varied separately. For instance, 30\%, 30\%, 31\%, and $41 \%$ of bone composition and $32 \%, 32 \%, 31 \%$, and $21 \%$ of blood waste were estimated from Harar, HU-Enterprise, Dire Dawa, and Haramaya abattoirs, respectively (Figure 1).

Field observation showed that a huge amount of abattoir wastes were disposed on surrounding environment. From four abattoirs, improper waste disposal system was observed as shown.

\subsection{Estimation of Greenhouse Gas Emission from Dumping} Sites. About 26.94 ton $\mathrm{CO}_{2}$ eq/year, 118.94 tonCO $\mathrm{CO}_{2}$ eq/year, 15.35 ton $\mathrm{CO}_{2}$ eq/year, and 20.39 tonCO $\mathrm{CO}_{2}$ eq/year of greenhouse gas emission were estimated from disposal sites of Harar Abattoir, Dire Dawa, Haramaya Abattoir, and Haramaya University Enterprise Abattoir, respectively (Table 2). As combined, about $181,630.74$ tonCO $\mathrm{CO}_{2}$ eq of greenhouse gas emission was estimated (Table 2) from 1,606.40 ton of abattoir waste estimated (Table 1) from the disposed sites of four selected abattoirs found in Eastern Ethiopia.

\subsection{Potential of Abattoir Waste}

3.3.1. Biogas Production and Its Cost. The table shows about $11,892 \mathrm{~m}^{3}$ /year, $53,826 \mathrm{~m}^{3} /$ year, $10,189 \mathrm{~m}^{3} /$ year, and $9,263.87 \mathrm{~m}^{3} /$ year of biogas production were estimated from Harar, Dire Dawa, Haramaya, and HU-E Abattoirs, respectively (Table 2). Using energy conversion coefficient equations, about 104,336.99 kWh/year, 282,049.65 kWh/year, $282,049.65 \mathrm{kWh} /$ year, and $48,542.68 \mathrm{kWh} /$ year of electricity and heat energy were estimated from Harar Town Municipality, Dire Dawa Administrative Municipality City Administration, Haramaya Town Municipality, and Haramaya University Enterprise Abattoirs, respectively (Table 3). When biogas is converted into cost, about $\$ 1,254.3, \$ 5,624.2$, $\$ 1,072.2$, and $\$ 971.1$ costs were estimated annually from Harar Abattoir, Dire Dawa Abattoir, Haramaya Abattoir, and HU-E Abattoir, respectively (Table 3).

3.3.2. Possible Reduction of Greenhouse Gases. Using IPCC [15], B-Sustain [14] and JGCRI [16] mathematical computa- tion model was applied. In the case of Harar Abattoir, from 26.94 ton $\mathrm{CO}_{2}$ eq/year of greenhouse gases/GHGs estimated from disposal sites could reduce 22.44 tonCO $\mathrm{CO}_{2}$ eq/year of GHG emission using $\mathrm{AD}$ and only 4.49 ton $\mathrm{CO}_{2}$ eq/year of GHGs was estimated from anaerobic digester (Table 4).

(1) Equivalence of Biogas with Other Fuel Fossil. The following table shows that from $85,139.20 \mathrm{~m}^{3} /$ year of biogas estimated could cover 36.10 ton of liquefied gas or 48.130 ton of kerosene or 280.758 ton of charcoal or 32.10 ton of furnace oil or 56.15 ton of petrol or 40.12 ton of diesel per year in the same functions (Table 5).

3.4. Biofertilizer Production and Its Cost. Using Deublien and Steinhauser [18], yield of biofertilizer [(DM - VS $)+(40 \% *$ VS)], about 16.502 ton/year, 72.852 ton/year, 9.404 ton/year, and 12.49 ton/year of biofertilizer, was estimated from Harar, Dire Dawa, Haramaya, and Haramaya University Enterprise Abattoirs, respectively (Table 6). When turned into cost, about 19.0 (542 ETB)/day and \$6,933.7 (198,025 ETB)/year; $\$ 85.9$ (2,454 ETB)/day and \$30,609.9 (874,220 ETB)/year; $\$ 16.3$ (465 ETB)/day and \$3,951.3 (112,850 ETB)/year; and $\$ 14.7$ (421 ETB)/day and \$5,248.3 (149,891 ETB) of biofertilizer were estimated from Harar Town Abattoir, Dire Dawa Administration Abattoir, Haramaya Abattoir, and Haramaya University Enterprise Abattoir, respectively (Table 6).

\section{Discussion}

4.1. Abattoir Waste Generation Rate. The study was sought to focus on abattoir waste generation from the selected Eastern Ethiopia abattoirs, namely, Harar Abattoir, Dire Dawa Abattoir, Haramaya Abattoir, and Haramaya University Enterprise Abattoirs. These abattoirs serve as slaughterhouse for slaughtering livestock such as cattle, goats, and sheep. Therefore, the researchers were considered these livestock in this study. The study revealed that the average number of livestock slaughtered in these two hundred forty-one per day and eighty-seven thousand nine hundred, sixty-five per year of livestock were slaughtered (Table 1).

Aniebo et al. [4] mathematical computation approach was used to estimate abattoir waste composition generated from the abattoirs during meat production due to its complexity and difficulty of abattoir waste. The main principal abattoir waste compositions considered in this study were blood waste, bone waste, intestinal content waste, and tissue that were considered in this assumption. However, the percentage of these abattoir waste compositions was varied 


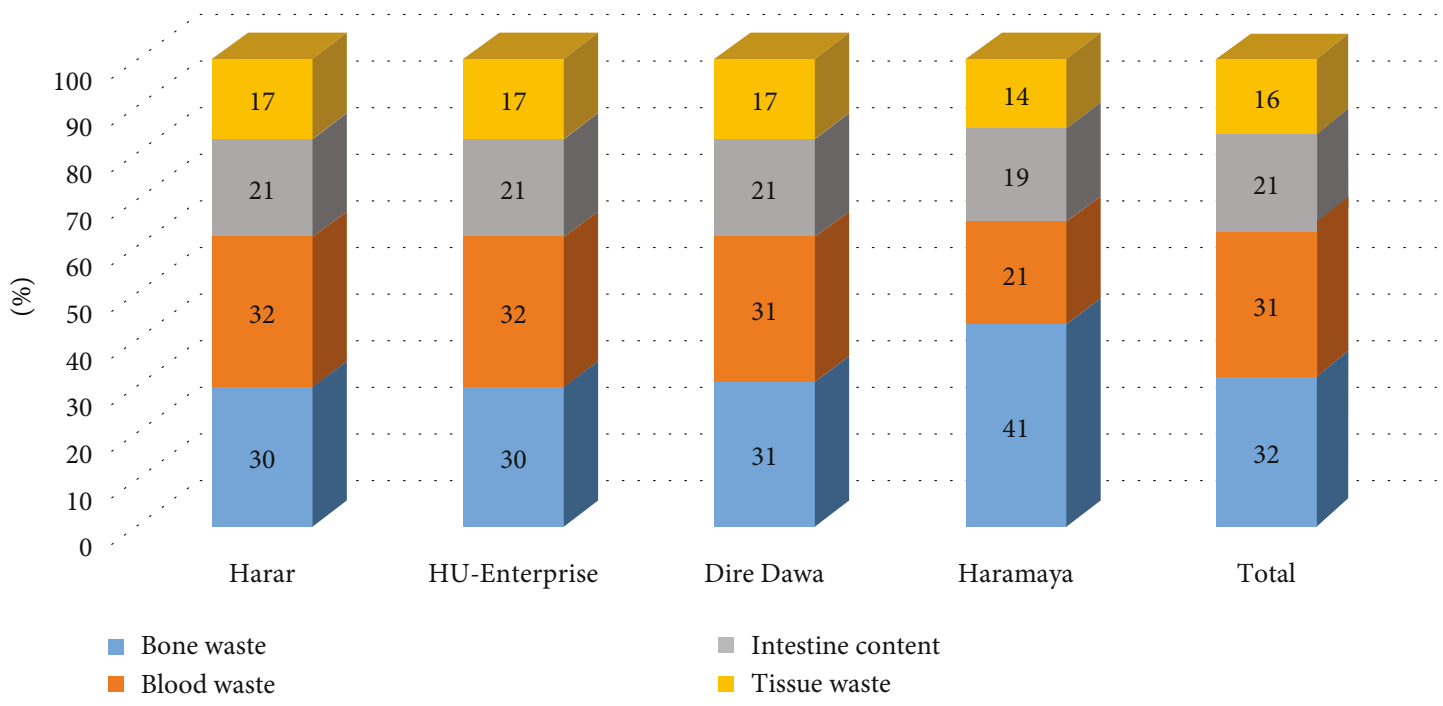

Figure 1: Percentage of waste composition rate of each abattoir from Dec. 1, 2018 to Jan. 2019.

TABLE 2: Annual estimation greenhouse gas emission from disposal sites of abattoirs, 2019.

\begin{tabular}{lcccc}
\hline \multirow{2}{*}{ Name of abattoirs } & \multicolumn{4}{c}{$\left.\begin{array}{c}\text { GHG emission from dumping sites } \\
(* \text { tonCO }\end{array}{ }^{-} \mathrm{e}\right)$} \\
& Daily & Weekly & Monthly & Annually \\
\hline Harar & 0.073 & 0.516 & 2.213 & 26.942 \\
Dire Dawa & 0.334 & 2.337 & 10.016 & 118.941 \\
Haramaya & 0.062 & 0.316 & 1.283 & 15.353 \\
HU-E & 0.057 & 0.401 & 1.718 & 20.393 \\
Grand total & 0.528 & 3.571 & 15.230 & 181.631 \\
\hline
\end{tabular}

$\mathrm{NB}: *$ tonCO ${ }_{2}{ }^{-} \mathrm{e}$ : a ton of carbon dioxide equivalent, also abbreviated as ton $\mathrm{CO}_{2}$ eq, is a metric measure used to compare the emissions from various greenhouse gases on the basis of their global warming potential (GWP).

generated among the selected abattoirs (Figure 1). That means the proportion of abattoir waste compositions generated from the selected abattoirs were not be same. This is because of slaughtered livestock type (such as cattle, goats, and sheep). For instance, when a high number of goat and sheep were slaughtered in abattoir, it resulted a high amount of bone that was estimated and followed by the blood, intestinal content, and tissue waste, respectively. Such type of waste composition estimation was observed in Haramaya and Dire Dawa Abattoirs. But, blood waste composition was the highest among abattoir waste compositions in Harar and Haramaya University enterprise where purely cattle were slaughtered and then followed by bone, intestinal content, and tissue waste composition, respectively (Figure 1). The study indicated abattoir waste generation produced throughout the year was varied among months due to livestock slaughtered were varied as the result of different fasting and meat-eating holidays. This is implies that from a high number of livestock, huge amount of abattoir waste could be produced from the selected abattoirs through the year.
The study revealed that half percent of abattoir waste generated during study period was from Dire Dawa Municipality Abattoir. While Harar Town Municipality, Hawassa University Enterprise Municipality, and Haramaya Town Municipality accounted the remaining percentage of abattoir waste compositions in a decreasing order (Figure 1). The present study indicated that more than six ton of abattoir waste was generated per day; annually, more than two thousand ton of abattoir waste was estimated from four selected Eastern Ethiopia abattoirs (Table 1).

As contrast, the current abattoir waste estimated (1,440.755 ton/year) and generated from Dire Dawa Municipality Abattoir is higher than that finding (923.995 ton/year) obtained from Hawassa Town Municipality found in South Ethiopia reported by Tolera et al. [19]. Similarly, it is higher than the waste that could be generated from Elfora Kombolcha Abattoir $(1,234.434$ ton/year) found in North Ethiopia, Adama Town Abattoir (895.621 ton/year) found in Southeast Ethiopia, and Mekele City Abattoir (8,345.678 ton/year) found in Northern Ethiopia, where slaughtered cattle were reported by Yesihak and Edward [20].

Moreover, it is also higher that the data recorded in Minna Abattoir, Abuja, Nigeria (873.810 ton/year) was reported by Ahaneku and Njemanze [21] and Tamale Municipality Abattoir, Ghana (778.910 ton/year) was reported by Frederick et al. [22]. However, the finding obtained from Harar Town Municipality Abattoir (494.819 ton/year), Haramaya Town Municipality Abattoir (432.640ton/year), and Haramaya University Enterprise Abattoir (424.860 ton/year) was smaller than the finding reported by ([20, 22]; [21]; [19]).

Moreover, the current abattoir waste generate could contrast with other organic municipality wastes that are generating from the nearby households in the same situation living in Eastern Ethiopia. Accordingly, the current estimated abattoir waste generated four abattoirs $(1,606.403$ ton/year) is higher than the municipality waste generated (154.391 ton/year) from 85 households of Aweday [23]. That means the present abattoir waste generating from four abattoirs is ten 
TABLE 3: Annual estimation of energy from estimated biogas of the selected abattoirs, Jan. 2019.

\begin{tabular}{|c|c|c|c|c|c|c|}
\hline \multirow{2}{*}{$\begin{array}{l}\text { Name of } \\
\text { abattoirs }\end{array}$} & \multirow{2}{*}{ Estimated waste (ton) } & \multirow{2}{*}{ Estimated biogas $\left({ }^{*} \mathrm{~m}^{3}\right)$} & \multicolumn{4}{|c|}{ Estimated energy from produced biogas and its cost } \\
\hline & & & Heat $\left({ }^{* *} \mathrm{kWh}\right)$ & Electricity (kWh) & Total energy (kWh) & Estimated cost $(* * * \$)$ \\
\hline Harar & 224.366 & $11,891.61$ & $25,448.1$ & $78,888.94$ & $104,336.99$ & $1,254.3$ \\
\hline Dire Dawa & $1,015.591$ & $53,826.27$ & $115,188.2$ & $166,861.4$ & $282,049.65$ & $5,624.2$ \\
\hline Haramaya & 192.253 & $10,189.25$ & $21,805.00$ & $31,586.7$ & $53,391.67$ & $1,072.2$ \\
\hline HU-E & 174.193 & $9,263.87$ & $19,824.68$ & $28,718.0$ & $48,542.68$ & 971.1 \\
\hline Grand total & $1,606.403$ & $85,139.20$ & $182,197.9$ & $263,931.5$ & $446,129.41$ & $8,901.6$ \\
\hline
\end{tabular}

${ }^{*} \mathrm{~m}^{3}$ : cubic meter $=1,000 \mathrm{~kg} .{ }^{* *} \mathrm{kWh}$ : kilowatt hour. ${ }^{* * *}$ United States dollar (USD): 1 = 28.5163: Ethiopian currency (ETB), April 2019.

TABLE 4: Estimation of potential reduction of GHG emission using anaerobic digester per year.

\begin{tabular}{|c|c|c|c|c|}
\hline \multicolumn{5}{|c|}{ Annual reduction of $\mathrm{GHGs}_{(\text {tonCO }} \mathrm{eq}$ ) using anaerobic digester } \\
\hline $\begin{array}{l}\text { Name of } \\
\text { abattoirs }\end{array}$ & $\begin{array}{c}\text { Estimated } \\
\text { waste (ton) }\end{array}$ & $\begin{array}{l}\text { GHG estimated } \\
\text { from dumping }\end{array}$ & $\begin{array}{l}\text { Estimated } \\
\text { of GHGs } \\
\text { from } A D\end{array}$ & $\begin{array}{l}\text { Potential } \\
\text { of } \mathrm{AD} \\
\text { reduction }\end{array}$ \\
\hline Harar & 224.366 & 26.942 & 4.486 & 22.437 \\
\hline $\begin{array}{l}\text { Dire } \\
\text { Dawa }\end{array}$ & $1,015.591$ & 118.941 & 20.312 & 101.558 \\
\hline Haramaya & 192.253 & 15.354 & 3.843 & 19.225 \\
\hline HU-E & 174.193 & 20.393 & 3.482 & 17.418 \\
\hline $\begin{array}{l}\text { Grand } \\
\text { total }\end{array}$ & $1,606.403$ & 181.631 & 32.127 & 160.640 \\
\hline
\end{tabular}

times than that of organic waste generated from eighty-five households $(10 * 154.391$ ton/year). In contrast, However, such a huge amount of abattoir waste generating across the country including Ethiopia either in governments' municipalities or owner enterprise abattoirs have no more attention to manage like other municipality wastes.

4.2. Estimation of Greenhouse Gases from Disposal Sites. Field observation indicated the current abattoir waste is simply disposed on an open environment without any disposal system (Figure 2). Many scholars reported improper disposal of wastes like abattoir waste which is one of the big problems for climate change all over the world due to greenhouse gases/GHGs/emission from their disposal sites [24]. Thus, to estimate greenhouse gas emission from disposal sites, the authors used IPCC [15] and GWP coefficient factors. Of these coefficient factors, it is possible to estimate the amount of GHG emission from four disposal sites of the selected abattoirs. Table 2 shows that more than twenty-six hundreds of ton of carbon dioxide equivalence of greenhouse gases (Table 2) was emitted from almost two hundred twentyfour ton of abattoir waste disposed site of Harar Town Abattoir per year (Table 1). In the same manner, more than one hundred nineteen ton of carbon dioxide equivalence of greenhouse gases (Table 2) was estimated from one thousand and fifteen ton of abattoir waste disposed at sites of Dire Dawa Administration City Municipality (Table 1). As combined, more than one hundred eighty-one ton of carbon dioxide equivalence of greenhouse gas emission (Table 2) was estimated from one thousand and six thousand ton of abattoir waste estimated from the disposed sites of four selected abattoirs found in Eastern Ethiopia (Table 1). Hence, such amounts of gases contribute to climate change and could enhance greenhouse effect and contribute on the sealevel rise and changes in rainfall patterns with implications for floods and droughts, and changes in the incidence of climatic as reported by Anthony et al. (2009). Hereby, these amounts of greenhouse gas emission from the disposal sites of the selected municipal abattoirs are one of the significant sources of air pollution at surrounding cities fully and at the national level in particular.

\subsection{Potential of Abattoir Waste}

4.3.1. Production of Biogas. The first product of aerobic digester is that it produces biogas, which is an environmentally friendly product. The current finding revealed that more than two hundred cubic meters of biogas production was estimated (Table 3) from four selected abattoirs and which could use for cooking, lighting, and heating. From this daily biogas production, more than one thousand kilowatts per hour of energy was estimated, and when turned into cost, more than twenty-five dollars or more than six hundred in Ethiopian currency (birr) price was estimated from these selected abattoirs (Table 3). Our country, Ethiopia, has been trying to install a big project for anaerobic breakdown of organic matter (e.g., animal or human waste, food waste, or plant material) ultimately alternative energy which is from biomass. For example, the country has been started the biogas implementation in the first Growth Transformation Program (GTP-I) and in the phase two (GTP-II) of strategic plan. This strategic plan has multitude of advantages to society and for forming sustainable environment, the wider dissemination of the technology [25], while GTP-II: alternative energy strategic to achieve national biogas program development goals of the second Growth and Transformation Plan (GTP-II) of the country should be a considerable focus on exploiting and initiating abattoir waste as raw materials that generated from other different abattoir operations found in the parts of the country (GTP II, 2016-2019/20). Therefore, our finding was inline and encouraged this strategic plan in order to any organizations or institutions found in the country could apply bioenergy from organic waste like abattoir waste as sustainable rather than disposing elsewhere.

The second benefit of AD through biogas is that it can lessen the impact of waste from surrounding climatic change (i.e., lesser emission of greenhouse gases into environment), which is currently the issue of world population and government politics. Thus, to do this, implementation of $\mathrm{AD}$ is 
TABLE 5: Equivalence of estimated biogas with other fossil fuels from the selected abattoirs, 2019.

\begin{tabular}{lccccccc}
\hline \multirow{2}{*}{$\begin{array}{l}\text { Name of } \\
\text { abattoirs }\end{array}$} & \multirow{2}{*}{ Estimated biogas $\left(\mathrm{m}^{3}\right)$} & \multicolumn{5}{c}{ Annual substitution of expensive fuels by utilization of biogas } \\
& & Liquefied gas (ton) & Kerosene (ton) & Charcoal (ton) & Furnace oil (ton) & Petrol (ton) & Diesel (ton) \\
\hline Harar & $11,891.61$ & 5.355 & 7.140 & 41.648 & 4.760 & 8.330 & 5.950 \\
Dire Dawa & $53,826.27$ & 23.640 & 31.520 & 18.388 & 21.013 & 36.774 & 26.267 \\
Haramaya & $10,189.25$ & 3.050 & 4.067 & 23.725 & 2.711 & 4.745 & 3.389 \\
HU-E & $9,263.87$ & 4.052 & 5.403 & 31.516 & 3.602 & 6.303 & 4.502 \\
Grand total & $85,139.20$ & 36.097 & 48.130 & 280.758 & 32.087 & 56.152 & 40.108 \\
\hline
\end{tabular}

NB: unit for biogas is cubic meter, while unit for all fossil fuels is ton (1 ton $=1,000$ kilograms).

TABLE 6: Estimation of biofertilizer production from abattoir waste of the selected abattoirs, 2019.

\begin{tabular}{lccccc}
\hline \multirow{2}{*}{ Name of abattoirs } & \multirow{2}{*}{ Abattoir waste (ton) } & \multicolumn{4}{c}{ Estimated residual for biofertilizer and its cost benefits } \\
& & Dry mass/DM (ton) & Volatile solid/VS (ton) & Biofertilizer (ton) & Estimated cost (US dollar) \\
\hline Harar & 224.37 & 33.68 & 28.63 & 16.502 & $6,933.7$ \\
Dire Dawa & $1,015.59$ & 148.68 & 126.38 & 72.852 & 30,610 \\
Haramaya & 192.25 & 19.19 & 16.31 & 9.404 & $3,951.3$ \\
HU-E & 174.19 & 25.49 & 21.67 & 12.491 & $5,248.3$ \\
Grand total & $1,606.40$ & 227.04 & 192.98 & 111.249 & $46,743.2$ \\
\hline
\end{tabular}

NB: United States dollar (USD) $1=28.5163$ Ethiopian currency (birr), April 2019 exchange.

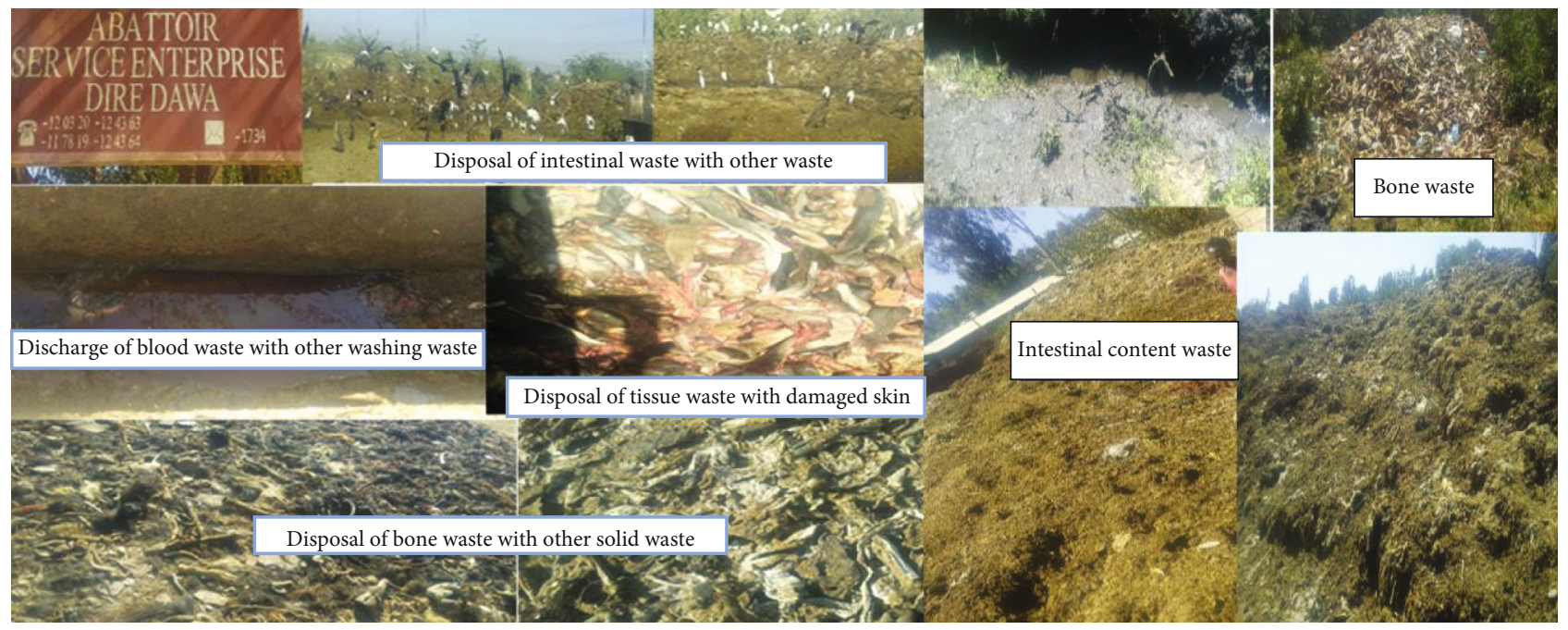

Figure 2: Waste disposal site of abattoir waste from the selected municipality abattoirs, March 2019.

significant. For example, Table 2 shows more than one hundred eighty-one ton of carbon dioxide equivalence of greenhouse gas emission (181.630 tonCO $\mathrm{CO}_{2} \mathrm{eq}$ ) (Table 2), which could avoid about one hundred sixty ton of carbon dioxide equivalence of greenhouse gases (160.640 ton $\mathrm{CO}_{2}$ eq) using anaerobic digester and almost only thirty-two ton of carbon dioxide equivalence of greenhouse gases (32.127 tonCO $\mathrm{CO}_{2} \mathrm{eq}$ ) could be emitted by anaerobic digester when it implemented based on the current finding (Table 2).

Moreover, substitution of biogas instead of other expensive fossil fuels is the third vital benefit of biogas. The second benefit of biogas is to substitute the other expensive fossil fuels such as liquefied petroleum gas, kerosene, charcoal, furnace oil, petrol, and diesel fuel with the equivalence functions and because biogas is a "cleaner" than these fuels [13]. For example, almost eighty-five thousand of estimated biogas could cover an average per capita consumption more than two hundred eighty ton of charcoal (Table 5). Essentially, charcoal and wood fire is common in immediate household to those who are living in the surrounding. So implementing this biogas project for each municipality abattoir could help more than 200 heads of households for their daily activities such as cooking, heating, and boiling water. Therefore, biogas has the potential to substitute the most expensive finite fossil fuels and charcoal with their drawback in the community. In the same manner, any project that consumed thirty-six ton of liquefied gas or fourth eight ton of kerosene or thirty-two ton of furnace or fifty-six of petroleum or fourth ton of diesel 
could be substituted by eighty-five thousand biogas estimated from the current abattoir waste generated (Table 2).

The fourth significant of anaerobic digester by means of biogas is that it is a supplementary for country's economy prosperity and social and sustainable development. In this study, the current finding shows that more than eight thousands of United States dollar $(\$ 8,901.6)$ was estimated from biogas estimated from four selected abattoirs per year. Scholars confirmed biogas improving economy of the country or abattoir itself through the means of creating markets for surrounding community by leading to lessen the cost [24].

4.3.2. Production of Biofertilizer. The second product of anaerobic digester is biofertilizer, the residual part of abattoir waste. The current study shows that about more than one hundred tons of biofertilizer was estimated per year from four selected abattoirs (Table 6). As the current estimated biofertilizer, it could cover two thousand two hundred and twenty-five hectares per year. Only not coverage as compare to chemical fertilizer, it could increase from $15 \%$ to $25 \%$ of total crop yield with advantage and efficiency of soil which was described under website and deal "Agronomies" [26]. Today, such benefits are important considerations for both government or users. Essentially, biofertilizer reduces water and soil pollution and loss of microorganisms and beneficial insects; overall reduction in soil fertility is one of the ill effects of chemical fertilizers. So, this study gives a clue of biofertilizer significance which holds promising future in reducing soil quality problems with optimum crop yield for users and farmers as well [26].

When turned into price, more than forty-six thousand United States dollars $(\$ 46,743.2)$ was estimated from four selected abattoirs found in Eastern Ethiopia (Table 6). The estimation was based on current chemical fertilizer price by considering market feasibility, which was considered how biofertilizer is perceived in terms of value offered for money spent by customers. In such circumstances, the researchers have decided the price of biofertilizers along with the risk and responses was weighed. In fact, the current price of chemical fertilizers or inorganic fertilizer used at the national level was less halved $(<50 \%)$ to estimate the cost of the current biofertilizer. That means such amount of price from inorganic fertilizer was reduced by half and the present estimated biofertilizer cost, which could be covered two times of hectares as compared to inorganic chemical coverage. On the other hand, this income generation is also supplementary of internal revenue for the abattoirs themselves.

Therefore, using anaerobic digestion for abattoir waste can provide subsequent generations a more healthy economy, a fairer and a more inclusive society, and a cleaner environment [24]. So, the present findings encourage 2 nd GTP targeted that recommended as "every governments" organization should increase their internal resource mobilization of income benefits not less than five percent of their governmental allocation" (i.e., $>5 \%$ of normal budget allocation from government) [27]. Moreover, AD has the potential to reduce pollutions and greenhouse gas emissions as compared to other waste treatments. In addition, it has ben- efits to mitigate global climate changes and optimize and keep soil health.

4.4. Limitation of Study. The research did not deal with the number of livestock slaughtered around homes or outside the selected abattoirs including slaughtered camels in these abattoirs. In addition, the magnitude of abattoir waste was estimated based on assumptions that were adopted from other African scholar contexts, which might lead to either lower or higher abattoir waste estimation record in these study areas due to the size of the cattle, sheep, and goats.

\section{Conclusion}

The present study shows that a large quantity of abattoir waste was generated as compared to other waste generated, which was directly disposed into the surrounding environment without any disposal system. The study also indicated that a huge amount of biogas and biofertilizer yield obtained through anaerobic digestion indicated that abattoir waste has potential benefits to ensure environmental safety and public health as means of sustainable management. Thus, the municipality should design abattoir waste treatment technology as sustainable management to safeguard the environment and ensure public health for the long-term plan, while proper abattoir waste disposal will forward as short term.

\section{Data Availability}

We consent the data deposit in a public repository that meets appropriate standards of archiving, citation and curation, and supplement information files under alongside of our manuscript; we can provide an explanation and details of any restrictions on access if data are not freely available, and acceptable justifications for restricting access may include legal and ethical concerns, such as third party rights, patient privacy, and commercial confidentiality.

\section{Conflicts of Interest}

The authors report no conflicts of interest in this work.

\section{Authors' Contributions}

Sina Temsgen Tolera contributed in developing the methods and conceiving the idea, participated in data collection and data analysis, analyzed the data, developed manuscript, and contributed in accepting comments from reviewers. Fekade Ketema Alemu involved in the data collection and facilitated the collection methods and entry of data into Excel for descriptive frequency, mean, and sum of the results. Both authors equally contributed to this study.

\section{Acknowledgments}

Mostly, we acknowledge Haramaya University in general and research "Theme I: Productivity and Environmental Sustainability for Food Security and Poverty Alleviation and Research Group and Partnership Directorate" of Haramaya University for the settled financial support which was coded 
as HUKT-2018-01-03-63. In addition, we thank Harar Town Municipality, Haramaya Town Municipality, Haramaya University Enterprise Abattoir, and all abattoir services who supported and facilitated the activities carried out at their abattoirs.

\section{References}

[1] FAO/Food and Agricultural Organization, Abattoir Development, Options and Designs for Hygienic Basic and MediumSized, Corporate Document Repository, 2010.

[2] S. M. Gauri, J. Kashaigili, and R. Kimwaga, "Insanitary and pose threats to health and technology in developing countries," vol. 97, no. 9, pp. 1119-1135, 2006.

[3] S. L. Ezeoha and B. O. Ugwuishiwu, "Status of slaughterhouse wastes research in Nigeria," Nigerian Journal of Technology, vol. 30, no. 2, pp. 143-148, 2011.

[4] A. O. Aniebo, S. N. Wekhe, and I. C. Okoli, "Abattoir blood waste generation in Rivers State and its environmental implications in the Niger Delta," Toxicological \& Environmental Chemistry, vol. 91, no. 4, pp. 619-625, 2009.

[5] J. Fearon, S. B. Mensah, and V. Boateng, "Abattoir operations, waste generation and management in the Tamale metropolis: case study of the Tamale slaughterhouse," Journal of Public Health and Epidemiology, vol. 6, no. 1, pp. 14-19, 2014.

[6] A. O. Akinro, I. B. Ologunagba, and O. Yahaya, "Environmental implications of unhygienic operation of a city slaughterhouse in Akure, Western Nigeria," ARPN Journal of Engineering and Applied Sciences, vol. 4, no. 9, pp. 60-63, 2011.

[7] D. O. Alonge, "Meat and milk hygiene; Ibadan, Nigeria," Farmcoe Press, vol. 64, no. 1, pp. 71-82, 2005.

[8] H. Roberts, L. de Jager, and G. Blight, "Waste-handling practices at red meat abattoirs in South Africa," Waste Management \& Research, vol. 27, no. 1, pp. 25-30, 2009.

[9] I. G. Adeyemi and O. K. Adeyemo, "Waste management practices at the Bodija abattoir, Nigeria," International Journal of Environmental Studies, vol. 64, no. 1, pp. 71-82, 2007.

[10] M. S. Rao, S. P. Singh, A. K. Singh, and M. S. Sodha, "Bioenergy conversion studies of the organic fraction of MSW: assessment of ultimate bioenergy production potential of municipal garbage," Applied Energy, vol. 66, no. 1, pp. 75-87, 2000.

[11] C. Ngumah, J. N. Ogbulie, J. C. Orji, and E. S. Amadi, "Biogas potential of organic waste in Nigeria," Journal of Urban and Environmental Engineering, vol. 7, no. 1, pp. 110-116, 2013.

[12] F. N. Rohstoffe, "Biogas basis daten Detsch land-comprehensive overview of the biogas station in Germany," 2009, December 2015.

[13] Charles Banks, "Optimization of anaerobic digestion to provide energy output via conversion," 2009, http://www .forestry.gov.uk/pdf/.../rrps_AD250309_optimising anaerobic_digestion.pdf.

[14] B-sustain, "Environmental and social benefits of biogas technology," 2013, March 2015, http://www.bsustain.in/faqs.html.

[15] IPCC/Intergovernmental Panel on Climate Change, National Greenhouse Gas Inventories and Uncertainty Management in National Greenhouse Gas Inventories, IPCC National Greenhouse Gas Inventory Program, 2000, http://www.ipcc-nggip .iges.or.jp/public/gp/gpgaum.htm.

[16] JGCRI/Joint Global Change Research Institute, GCAM v4.4 Documentation: Global Change Assessment Model (GCAM),
Documentation for GCAM, 2018, June 2018, http://jgcri .github.io/gcam-doc/.

[17] EEPCO/Ethiopian Electric Power Corporation, 2018, http:// www.ethio.energyconversionresource.

[18] D. Deublien and A. Steinhauser, Biogas from Waste and Renewable Resources, Wiley-VCH Verlag GmbH \& Co, 2008.

[19] S. T. Tolera, S. S. Sota, E. Derebie, and T. H. Mekonnen, "Waste generation and physicochemical qualities of abattoir wastewater in Hawassa City, Southern Ethiopia," East African Journal of Health and Biomedical Sciences, vol. 3, no. 1, pp. 1320, 2019.

[20] Y. Y. Mummed and E. C. Webb, "Operation, facilities and management in public and private abattoirs in Ethiopia," African Journal of Agricultural Research, vol. 10, no. 7, pp. 623-630, 2015.

[21] I. E. Ahaneku and C. F. Njemanze, "Material flow analysis of abattoir solid waste management system in Minna, Nigeria," The Journal of Solid Waste Technology and Management, vol. 41, no. 2, pp. 165-172, 2015.

[22] A. Frederick, T. G. Ayum, A. A. Gifty, and A. Samuel, "Microbial quality of chevon and mutton sold in Tamale metropolis of Northern Ghana," Journal of Applied Sciences and Environmental Management, vol. 14, no. 4, pp. 53-55, 2010.

[23] S. Beneberu, "Generation, composition and characteristics of urban solid waste in a major khat producing and marketing area in Eastern Ethiopia," International Journal of Environmental Protection, vol. 1, no. 5, pp. 9-16, 2011.

[24] O. Chukwu, P. A. Adeoye, and I. Chidiebere, "Abattoir wastes generation, management and the environment: Minna, Nigeria," International Journal of Biosciences, vol. 1, no. 6, pp. 100-109, 2011.

[25] NBP/National Biogas Program, "First Ethiopian strategic plan (2010-2015 years)," 2007, http://www.biogas in Ethiopia.

[26] R. Kholkute, "Biofertilizers_opportunities_and_challenges_ .pdf," 2013, http://www.ifaj.org.RK.

[27] NPC/National Planning Commission, Federal Democratic Republic of Ethiopia Growth and Transformation Plan II (GTP II) (2015/16-2019/20), 2016. 